\title{
A Look at the Liquidity Management Practices of Banks in South Africa
}

\author{
Tafirei Mashamba, Farai Kwenda \\ Lecturer, Great Zimbabwe University, Masvingo, Zimbabwe \\ University of KwaZulu-Natal, Durban, South Africa \\ tmashamba@gzu.ac.zw, kwendaf@ukzn.ac.za
}

\begin{abstract}
In an effort to strengthen bank liquidity-risk management practices, the Basel Committee proposed new liquidity requirements for banks in 2010 under the Basel III framework. However, despite the good intentions of the liquidity requirements the new regulations are likely to present some challenges for banks in the course of managing their liquidity. However, before any inference can be made about the possible implications of the liquidity standards on bank liquidity management practices, it is imperative to have insight into the current liquidity management strategies of banks. This paper seeks to determine the current liquidity management practices of banks in South Africa by examining whether South African banks have target liquidity levels which they pursue and also by determining the variables that drive bank liquidity ratios. The study sample comprised six commercial banks operating in South Africa over the period 1993 to 2009. For analysis, a partial adjustment model was developed and estimated using the generalized method of moments (GMM) estimator. The rate at which South African banks adjust their balance sheets was estimated at $8 \%$. This adjustment speed implies that South African banks adjust their balance sheets slowly - probably due to high adjustment costs. Thus, South African listed banks have passively managed their liquidity and partially adjust their liquidity levels in an attempt to reach the optimal level. Furthermore, the following variables were considered to be the main drivers of liquidity ratios in South Africa: bank size, capital adequacy, loan loss reserves, and financial crisis.
\end{abstract}

\section{Keywords: Liquidity management, commercial banks, South Africa, partial adjustment model, GMM}

\section{Introduction}

During the global financial turmoil that began in mid2007, many banks experienced liquidity problems. Bank liquidity problems reached a climax in late 2008, following the failure of Lehman Brothers in September 2008. Farag et al. (2013) and Vodová (2013) attributed liquidity problems that banks faced to imprudent liquidity-management practices. The fact that liquidity was easily, cheaply and readily available, made banks complacent in terms of their liquidity management (Basel Committee on Banking Supervision, 2010). Similarly, Accenture (2015) observed that banks did not develop proper liquidity projection models and over relied on volatile short-term wholesale funds like Repurchase Agreements (Repos) and Asset Backed Commercial Paper (ABCP) to finance their activities. At the same time, banks invested heavily in structured products like Asset Backed Securities (ABS) which are vulnerable to illiquidity during episodes of severe financial distress such as occurred during the 2007 to 2009 financial turmoil (Kowalik, 2013). Bank liquidity can be described as the dexterity of a bank in funding asset growth and paying off obligations as they fall due (Basel Committee on Banking Supervision, 2008). Liquidity is vital to the ongoing viability of a bank; therefore, liquidity management ought to be a routine activity in bank operations. Liquidity management is not only important at individual bank level, because liquidity shortfalls are contagious (Basel Committee on Banking Supervision, 2000). A shortfall at one bank (especially systemically important banks) can quickly transcend to other banks - causing system-wide disturbances.

The need for banks to efficiently manage their liquidity stems from their maturity-transformation function in the economy. Typically, banks accept short-term deposits from surplus economic units and issue long-term loans to deficit economic units. Banks engage in maturity transformation on the assumption that depositors will not make 'enmasse' withdrawals (Elliot, 2014)- or that they can easily replenish withdrawals with new deposits. However, during periods of financial crisis, depositors can lose confidence in a bank or the banking system as a whole (due to solvency concerns), and engage in panic withdraws (Covas and Driscoll, 2014). Under these circumstances, if the troubled institution(s) do not have adequate liquidity buffers or fail to get external support timeously, they are likely to experience "bank runs" and failure becomes inevitable (Vodová, 2013). Thus, liquidity management remains one of the most important occupation of bank managers (Basel Committee on Banking Supervision, 2000). 
Liquidity management is connected to both sides of a bank's balance sheet. It looks at the optimal mix of assets and liabilities that a bank needs to hold on an ongoing basis in order to remain liquid. Banks can ameliorate liquidity risk by financing themselves with fairly stable funding sources (mainly retail deposits) that are resilient - even during episodes of market-wide stress. Furthermore, banks can build liquidity buffers during good times, which they draw down during episodes of crisis - especially when the bank cannot renew its funding sources or when other assets are illiquid (Farag et al., 2013). Besides stable funding sources, bank managers can mitigate liquidity risk by holding a large stock of liquid assets such as treasury bills, central bank reserves, quasi-government securities, sovereign bonds, and non-financial corporate bonds. These securities can be liquidated when the need arises in order to cover liquidity shortfalls. Despite acting as a cushion against liquidity shortages, liquidity buffers however have a signaling effect. A bank with a large stock of liquid assets signals its ability to pay off imminent liabilities to the market (Aspachs et al., 2005). For this reason, liquidity buffers build depositor confidence in the institution, which prevents panic withdrawals and ultimately reduces demand for withdrawals. Banks can also make use of the interbank market to meet their liquidity needs on a daily basis. However, this source of liquidity can be unreliable because it is susceptible to systemic disturbances and can even dry up - as occurred during the 2007 to 2009 financial crisis.

In an effort to strengthen bank liquidity-risk management practices, the Basel Committee on Banking Supervision proposed new liquidity requirements for banks in 2010 under the Basel III framework - in the form of the Liquidity Coverage Ratio (LCR) and the Net Stable Funding Ratio (NSFR). The two rules have different but complementary objectives. The LCR aims to promote a bank's short-term resilience in terms of liquidity shocks - by demanding that it holds adequate, high quality liquid assets (HQLA). The NSFR seeks to minimize liquidity risk (asset and liability mismatches) by ensuring that banks finance their activities with long-term stable sources of funding (Basel Committee on Banking Supervision, 2010). Despite their significance, however, the new liquidity regulations are likely to present some challenges for banks in managing their liquidity - because banks have never before been exposed to binding liquidity charges. ${ }^{1}$

Before any inference can be made about the possible implications of liquidity standards on bank liquiditymanagement practices, it is imperative to have insight into the current liquidity-management strategies of banks. In this regard, DeYoung and Jang (2016) state that if banks actively manage their balance sheet liquidity, then blanket imposition binding of liquidity regulations would only have idiosyncratic effects on bank liquidity management. On the other hand, if banks passively manage their liquidity, then blanket imposition of mandatory liquidity charges would have systematic effects on bank balance-sheet liquidity management and their ability to extend credit. Therefore, this study sought to investigate liquidity management practices being pursued by South African banks. In particular, this paper examines whether South African banks actively or passively managed their balance sheet liquidity during the period under review.

\section{Literature Review}

To gain insights into liquidity-management practices of banks, Schertler (2010) examined how German banks manage their regulatory liquidity based on three stylized strategies: liquidity purchases, cash-flow matching, and accounting exchanges. Using a dynamic panel regression model on a quarterly dataset covering the period 2000 to 2008 on three types of banks in Germany - commercial, savings and cooperative Schertler found that banks have diverse liquidity-management strategies which are based on their type. Commercial banks were found to depend more on capital (wholesale) markets for funding, while savings and cooperative banks concentrated on cash-flow matching - i.e. they match cash inflows and outflows between assets and liabilities in each time bucket, in order to manage their liquidity. All three forms of banks were found to engage in asset side accounting exchanges, and also cutting back lending when confronted with higher payment obligations from maturing obligations. De Haan and van den End (2013) examined how banks react to funding liquidity disturbances emanating from financial market volatility, using a dataset of the 17 largest Dutch banks for the period January 2004 to April 2010. They modeled bank liquidity dynamics using a panel Vector Autoregressive specification. Orthogonal impulse response showed that banks react to

\footnotetext{
${ }^{1}$ Until 2010 there were no liquidity requirements for banks - only capital charges existed.
} 
funding gaps in three stylized ways: (i) reducing lending, particularly wholesale; (ii) hoarding liquidity, mainly liquid bonds and central bank reserves; and (iii) engaging in fire sales, particularly equity.

Duijm and Wierts (2014)applied the Fully Modified OLS (FMOLS) estimator to examine the long-run relationship between actual and required liquidity for Dutch banks and evaluated bank balance sheet adjustment dynamics. They established a long-run relationship between liquid assets and liabilities, and therefore went on to develop an Error Correction Model (ECM) to identify how banks rebalance their balance sheets when confronted with liquidity shocks. The ECM shows that Dutch banks adjust their liquidity on the liability side - particularly when they are off their target liquidity level. Furthermore, the Dutch LCR (macro prudential regulation) was found to be weak in stemming aggregate liquidity cycles, as evidenced by procyclical trends in balance sheet size and risk-taking behavior of banks. DeYoung and Jang (2016) examined whether US commercial banks have target liquidity levels which they pursue, and how fast they adjusted their balance sheets to revert to their target liquidity ratios for the period 1992 and 2012. For analysis, they developed a partial adjustment model similar to that of Berger et al. (2008), and estimated the model using Blundell and Bond's (1998) generalized method of moments estimator. DeYoung and Jang established that US commercial banks actively managed their liquidity during the period 1992 to 2012 .

\section{Methodology}

Empirical Model: The methodology of this paper is drawn from capital-management studies that explored bank capital-management practices. Accordingly, the researchers developed a partial adjustment model in line with Berger et al. (2008), Flannery and Hankins (2013) and (Kok and Schepens, 2013). Firstly, the researchers specify and estimate a model of the factors that influence banks' target liquidity of the form:

Where:

$$
L I Q_{i t}^{*}=\beta X_{i, t-1}
$$

$\mathrm{LIQ}_{\mathrm{it}}{ }^{*} \quad$ : is the target liquidity level for bank i at time $\mathrm{t}$, which is perceived to vary across banks and over time. Bank liquidity level was proxied by the liquid asset ratio (LaR).

$\beta \quad$ : is a vector of coefficients to be determined.

$X_{\mathrm{i}, \mathrm{t}-1} \quad$ : is a vector of bank specific characteristics that influence bank liquidity (see Table 1 ).

The bank's target liquidity is assumed to oscillate around an unobservable target. In each time period the bank looks at deviations from the target and takes appropriate action to close the gap. Due to adjustment costs, banks may not be able to instantly close the gap, so leading to the following partial adjustment model:

$L I Q_{i t}-L I Q_{i, t-1}=\lambda\left(L I Q_{i t}^{*}-L I Q_{i, t-1}\right)+\varepsilon_{i t}$

Where:

$\lambda \quad:$ is the speed of adjustment.

$\varepsilon_{\text {it }} \quad:$ is the error term

If $\lambda$ is high, it indicates that banks are actively managing their liquidity and face minimal adjustment costs. On the other hand, if $\lambda$ is low, it means that banks are passively managing their liquidity and face substantial adjustment costs.

Considering that the target liquidity is not directly observable, Equations (1) and(2) are integrated and rearranged to yield:

$$
L I Q_{i t}-L I Q_{i, t-1}=\lambda\left(\beta X_{i, t-1}\right)+(1-\lambda) L I Q_{i, t-1}+\varepsilon_{i t}
$$

From equation (3), the complete model can be specified as:

$L I Q_{i t}=\alpha+\lambda L I Q_{i, t-1}+\beta_{1} S_{I Z E_{i t}}+\beta_{2} C A R_{i t}+\beta_{3} N I I_{i t}+\beta_{4} L L R_{i t}+\beta_{5}$ Ownership $_{i t}+\beta_{6} F C_{t}+\varepsilon_{i t}$

Equation (4) enables us to estimate the bank's target liquidity level, establish the cross-sectional bankspecific variables that influence bank liquidity ratios, to estimate bank adjustment speed towards their desired liquidity level rate, and to investigate whether banks actively or passively manage their liquidity. 
Equation (4) is estimated using system Generalised Method of Moments (GMM) developed by Blundell and Bond (1998)- for the following reasons. As pointed out by Arellano and Bover (1995), Blundell and Bond (1998) and Roodman (2009), system GMM can eliminate autocorrelation arising from the inclusion of the lagged dependent variable among covariates, endogeneity problems emanating from the correlation of the one or more covariates with the error term, or omitted variable bias and unobserved heterogeneity due to differences in firm characteristics like management quality, organization culture, investment policies, and which static panel regression models like random effect, fixed effect and pooled ordinary least squares cannot handle. In addition, system GMM overcomes the weak instrument problem in the difference GMM estimator (Blundell and Bond, 1998). System GMM estimator furthermore caters for biased adjustment speeds which arise in the dynamic structure of the model (Kok and Schepens, 2013).

Data and Variables: The study sample was drawn from six commercial banks operating in South Africa over the period 1993 to 2009. The choice of commercial banks was based whether they were more involved in maturity transformation relative to other forms of banks. The study focuses on bank-specific drivers of liquidity. LikeMarozva (2015) and Molefe and Muzindutsi (2016), data for the study were sourced from the BFA McGregor database, because it is the most comprehensive database containing financial statements of firms (financial and non-financial) listed on the Johannesburg Stock Exchange. Based on Bonner and Hilbers (2015) and Delechat et al. (2012), bank-specific variables considered in this study were (see Table 1, below):

Table 1: Bank-specific characteristics that influence the LDR

\begin{tabular}{|c|c|c|c|}
\hline Variable & Description & Measurement & $\begin{array}{l}\text { Expected } \\
\text { Sign }\end{array}$ \\
\hline $\begin{array}{l}\text { Liquid asset } \\
\text { ratio (LaR) }\end{array}$ & $\begin{array}{l}\text { Dependent varia } \\
\text { Measure of bank liquidity that } \\
\text { reflects the ability of the bank to } \\
\text { absorb liquidity shocks. } \\
\text { Independent vari }\end{array}$ & $\frac{\text { Totalliquidassets }_{i t}}{\text { Totalassets }_{i t}}$ & $\begin{array}{l}\text { Dependent } \\
\text { variable }\end{array}$ \\
\hline $\begin{array}{l}\text { Bank- } \\
\text { specific }\end{array}$ & & & \\
\hline $\begin{array}{l}\text { Lagged LDR } \\
\text { Net interest } \\
\text { income to } \\
\text { Earning } \\
\text { Assets (NII) }\end{array}$ & $\begin{array}{l}\text { Lagged dependent variable } \\
\text { Profitability measure: Profitable } \\
\text { banks are expected to hold lower } \\
\text { levels of liquidity, since they are } \\
\text { perceived to have a low default } \\
\text { probability and they are less liquidity } \\
\text { constrained. }\end{array}$ & $\begin{array}{c}\text { LaggedLaR }_{i t}=\text { LaR }_{i, t-1} \\
\text { Interestearned }_{i t}-\text { interestpaid }_{i t} \\
\text { EarningAssets }_{i t}\end{array}$ & $\begin{array}{l}\text { Positive } \\
\text { Negative }\end{array}$ \\
\hline $\begin{array}{l}\text { Capital } \\
\text { Adequacy } \\
\text { Ratio (CAR) }\end{array}$ & $\begin{array}{l}\text { Measures the soundness of a bank. } \\
\text { Healthy banks are expected to hold } \\
\text { lower liquidity because of their } \\
\text { favorable access to external debt } \\
\text { funding. }\end{array}$ & $\frac{\text { EquityCapital }_{i t}+\text { RetainedEarnings }_{i t}}{\text { RiskWeghtedAssets }_{i t}}$ & Negative \\
\hline $\begin{array}{l}\text { Loan Loss } \\
\text { Reserves } \\
\text { (LLR) }\end{array}$ & $\begin{array}{l}\text { Illustrates the riskiness of the loan } \\
\text { portfolio. The riskier the loan } \\
\text { portfolio, the more liquid the bank is } \\
\text { expected to be. }\end{array}$ & $\frac{\text { Bad\&DoubtfuldebtsProvision }_{i t}}{\text { GrossAdvances }_{i t}}$ & Positive \\
\hline $\begin{array}{l}\text { Bank Size } \\
\text { (SIZE) }\end{array}$ & $\begin{array}{l}\text { Big banks are expected to be less } \\
\text { liquid because of their easy access to } \\
\text { debt markets. }\end{array}$ & $\begin{array}{l}\text { Natural log of Total Assets (Excluding } \\
\text { Intangible Assets) }\end{array}$ & Negative \\
\hline $\begin{array}{l}\text { Ownership } \\
\text { (Ownership) }\end{array}$ & $\begin{array}{l}\text { Foreign banks, due to their access to } \\
\text { external parent company support, } \\
\text { are expected to hold low levels of } \\
\text { liquidity. }\end{array}$ & $\begin{array}{l}\text { Dummy variable with the value of } 1 \text { for } \\
\text { domestic ownership and } 0 \text { for foreign } \\
\text { ownership. Foreign banks, because of } \\
\text { their access to parent company } \\
\text { support, are expected to hold lower } \\
\text { levels of liquidity compared to their } \\
\text { domestic counterparts. }\end{array}$ & $\begin{array}{l}\text { Negative } \\
\text { for foreign } \\
\text { and } \\
\text { positive } \\
\text { for local }\end{array}$ \\
\hline
\end{tabular}




\begin{tabular}{ll}
\hline FC & Dummy variable to account for the Dummy variable which takes the value Positive \\
financial crisis. It is presumed that of 1 for the period of the crisis - i.e. & \\
financial crisis motivates banks to 2007 to 2009; otherwise the value is 0. & \\
increase their liquidity buffers to \\
mitigate liquidity risk which may \\
arise from bank runs or large \\
unexpected cash withdrawals.
\end{tabular}

Source: Researchers' own design.

Unit root test: Before running regression models, Gujarati and Porter (1999) recommend that it is imperative to first check for unit roots in the data in order to prevent spurious regression. Accordingly, all the variables were tested for stationarity using the Maddala and $\mathrm{Wu}$ unit root test which is applicable to unbalanced panel data (Baltagi, 2005). The panel dataset employed in this paper is unbalanced due to some missing observations; thus, the Maddala and Wu test was regarded to be the most appropriate test.

\section{Results and Discussion}

Descriptive Statistics: Table 2 (below) presents estimates of descriptive statistics:

Table 2: Descriptive Statistics

\begin{tabular}{lllll}
\hline Variable & Mean & Standard deviation & Min & Max \\
\hline LaR & 65.50423 & 16.5014 & 29.6275 & 85.5079 \\
NII & 10.48168 & 19.92949 & 2.1346 & 83.6508 \\
LLR & 88.81537 & 65.73206 & 35.0698 & 410.0575 \\
SIZE & 11.76143 & 1.943447 & 6.074035 & 14.22341 \\
CAR & 13.03774 & 13.40593 & 5 & 83.4 \\
\hline
\end{tabular}

Source: Model output.

The average liquid asset ratio for the period under review was estimated at $65.50 \%$, which is relatively high. This ratio means that for every R1.00 received by banks, R0.655 is maintained in liquid assets. This suggests that South African banks are very liquid and thus can withstand severe liquidity shocks. The average net interest income to earning assets ratio was estimated to be $10.48 \%$ for the period under review. This ratio implies that commercial banks in South Africa - for the period under investigation - have been able to earn $10.48 \%$ from their earning assets. This indicates that South African banks are profitable and can efficiently 'sweat' their capital. The ratio of loan loss reserves to gross advances was estimated to be $88.82 \%$, which is fairly high, and indicates that South African banks are very conservative; they manage liquidity risk prudently by keeping a large buffer of provisions to cater for bad debts. Turning to capital adequacy, the average Tier 1 ratio was $13.04 \%$. This figure suggests that South African banks are adequately capitalized, considering that they are above the minimum capital adequacy ratio of $8 \%$ set by the Basel Committee on Banking Supervision.

\section{Pairwise Correlation}

Table 3 presents results of pair correlation analysis.

Table 3: Correlation matrix

\begin{tabular}{lllllll}
\hline Variable & LaR & LagLaR & NII & LLR & SIZE & CAR \\
\hline LaR & 1.0000 & & & & & \\
LagLaR & 0.9124 & 1.0000 & & & & \\
NII & -0.4826 & -0.3807 & 1.0000 & & & \\
LLR & -0.2037 & -0.2407 & 0.4419 & 1.0000 & & \\
SIZE & 0.3503 & 0.3567 & -0.5936 & -0.0739 & 1.0000 & \\
CAR & -0.3892 & -0.4798 & -0.0143 & -0.0213 & -0.7133 & 1.0000 \\
\hline
\end{tabular}

Source: Model output. 
From the correlation matrix (Table 3) it can be shown that data used for the study does not exhibit multicollinearity, because the correlation among independent variables is low; in all cases it is below $60 \%$ save for the lagged dependent variable which is $91.24 \%$. The high correlation of the lagged dependent variable with the regress and indicates persistence - that is to say past values of the dependent variable influence future values. Therefore, current values of the liquid asset ratios are heavily influenced by their past values. According to Gonzale et al. (2007) and Louzis and Vouldis (2015), if the dependent variable exhibits persistence, the best model to use for fitting the data will be a dynamic error component (partial adjustment) model. This justifies the adoption of a partial adjustment model in this paper.

Unit Root Test Results: As shown in the Appendix, the results of the unit root test demonstrate that all the variables are stationary; hence, they can be regressed without problems of unit roots. All variables were stationary at the $5 \%$ significance level - save for bank size which became stationary at the $10 \%$ significance level.

\section{Empirical Results}

Results of regressing equation 4 with system GMM are presented in Table 5.

Table 5: Model results

\begin{tabular}{lllll}
\hline Variable & Coefficient & Standard Error & p-value & $\begin{array}{l}\text { Significance } \\
\text { level }\end{array}$ \\
\hline Constant & 0.8023089 & 0.5478032 & 0.143 & $5 \%$ \\
Lagged LaR & 0.9223649 & 0.0469652 & 0.000 & $5 \%$ \\
NII & 0.0017551 & 0.0077879 & 0.822 & $5 \%$ \\
LLR & 0.0791261 & 0.0230416 & 0.001 & $5 \%$ \\
SIZE & -0.713565 & 0.4233576 & 0.427 & $10 \%$ \\
CAR & -0.022192 & 0.0279324 & 0.000 & $5 \%$ \\
FC & 0.0529322 & 0.021442 & 0.014 & $5 \%$ \\
Ownership & -0.0053233 & 0.0050777 & 0.294 & $5 \%$ \\
\hline
\end{tabular}

Source: Model output.

Lagged Dependent Variable: The coefficient of lagged LDR is positive and statistically significant at 5\%. The significance of this variable implies that current values of liquidity ratios are influenced by their past values. In other words, these results demonstrate that liquidity ratios are persistent. Therefore, the partial adjustment model used in this study is justified. The rate at which South African banks adjust their liquidity following a liquidity shock was estimated to be 0.077635 , i.e. (1-0.92236). This adjustment speed is relatively low - implying that South African banks face high adjustment costs, since a low speed of adjustment is associated with high adjustment costs. Taken as a whole, the study established that South African listed banks have passively managed their liquidity and they partially adjust their liquidity levels in an attempt to reach the optimal level.

Size: $A$ priori, a negative relationship was expected between liquidity and firm size. To the expectation of researchers, results indicate a negative association (coefficient of $-71.36 \%$ ) between liquidity and bank size. Therefore, in the South African context, bank size can be considered to have a significant influence on the liquidity holdings of banks. Thus, the bigger the size of the bank, the less liquidity it maintains. These findings concur with DeYoung and Jang (2016) - who established that size positively influences the loan to deposit ratio in the United States.

Net Interest Income: Contrary to researchers' expectations, the coefficient for net interest income is positive, although statistically insignificant. The lower explanatory power of this variable suggests that profitability does not influence commercial banks in South Africa to hold liquidity buffers. Such findings can be explained by the fact that as an emerging market, South African banks are more tailored towards the traditional intermediation function of deposit collection and loan extension - with less reliance on debt funding. 
Loan Loss Reserves: As predicted, the relationship between liquidity and loan loss reserves is positive and statistically significant. This confirms the hypothesis that banks hold more liquid assets to self-insure against potential defaults. Delechat et al. (2012) also established that banks which are perceived to be risky increase their loan loss reserves, which ultimately boosts their liquidity.

Capital Adequacy Ratio: A negative statistically significant association between liquidity and capital adequacy was identified, as expected. This result can be explained by the fact that capital regulations motivate banks to hold low risk weight assets which are generally liquidity (Bonner and Hilbers, 2015). Furthermore, healthy institutions are expected to hold lower liquidity because of their favorable access to funding markets. However, these findings contradict Vodova (2013) who established that capital does not significantly influence the liquidity holdings of banks in the Visegrad Group.

Financial Crisis: A significant, positive correlation was identified between liquidity and financial crisis. These findings imply that the recent global financial crisis significantly influenced commercial banks in South Africa to boost their level of liquidity - in order to manage liquidity risk which could emanate from bank runs or large unexpected cash withdrawals. Therefore, it can be argued that crisis periods induce banks to increase their liquidity holdings. Nevertheless, Vodova (2013) provides contradicting results, and found that the recent financial crisis did not significantly influence Visegrad banks to hold more liquid assets.

Ownership Structure: Since $75 \%$ of banks used in the study are indigenous, a priori the researchers expected the relationship between liquidity and ownership to be positive. Nevertheless, our study indicates a weak, negative and statistically insignificant relationship between liquidity and ownership. From these findings it can be argued that ownership does not significantly influence the liquidity holdings of banks in South Africa - contrary to Delechat et al. (2012) who found that ownership positively influences banks to hold liquid assets in Central America.

\section{Conclusion}

The main aim of this study was to shed light on the current liquidity-management practices of banks in South Africa. This aim was achieved by examining whether South African banks have target liquidity ratios which they pursue and by establishing the main drivers of bank liquidity ratios. The study results indicate that bank size, capital adequacy, loan loss reserves and financial crisis significantly influence bank liquidity holdings. On the other hand, net interest income and ownership were found to have a low explanatory power relative to banks' desire to hold liquidity. Turning to the adjustment speed, the rate at which South African banks adjust their balance sheets following a liquidity shock was estimated to be approximately $8 \%$. This implies that the adjustment speed is relatively slow hence - and hence these banks face high adjustment costs. Consequently, South African commercial banks passively manage their liquidity. In other words due to high adjustment costs, these banks take time to revert to their target liquidity levels. Furthermore, liquidity ratios were persistent over time. Based on these findings, it can be suggested that a blanket imposition of mandatory liquidity charges in South Africa would have systematic effects on banks' balance-sheet liquidity management, and also their ability to extend credit to the real economy.

\section{References}

Accenture (2015). Liquidity Coverage Ratio online document, available at:https://www.accenture.com/usen/insight-liquidity-coverage-ratio-banking.aspx

Arellano, M. \& Bover, O. (1995).Another look at the instrumental variable estimation of error-components models. Journal of Econometrics, 68(1), 29-51.

Aspachs, O., Nier, E. \& Tiesset, M. (2005).Liquidity, banking regulation and the macro economy. Evidence on bank liquidity holdings from a panel of UK-resident banks. Unpublished manuscript, BIS.

Baltagi, B.H. (2005). Econometric analysis of panel data (3 $3^{\text {rd }}$ Edition).England: John Wiley \& Sons.

Basel Committee on Banking Supervision. (2000). Sound practices for managing liquidity in banking. Switzerland: Bank for International Settlements.

Basel Committee on Banking Supervision. (2008). Principles for sound liquidity management and supervision. Switzerland: Bank for International Settlements. 
Basel Committee on Banking Supervision. (2010). Basel III: International framework for liquidity risk measurement, standards and monitoring. Switzerland: Bank for International Settlements.

Blundell, R.\& Bond, S. (1998). Initial conditions and moment restrictions in dynamic panel data models. Journal of Econometrics, 87(1), 115-143.

Bonner, C.\& Hilbers, P. (2015). Global liquidity regulation: Why did it take so long?Netherlands Central Bank, Research Department.

Covas, F.\& Driscoll, J. (2014). Bank liquidity and capital regulation in general equilibrium. FEDS Working Paper No. 2014-85.

De Haan, L.\& Van den End, J.W. (2013). Banks' response to funding liquidity shocks: Lending adjustment, liquidity hoarding and fire sales. Journal of International Financial Markets, Institutions and Money, $26,152-174$.

Delechat, C., Arbelaez, C.H., Muthoora, M.P.S.\& Vtyurina, S. (2012). The determinants of banks' liquidity buffers in Central America (No. 12-301). International Monetary Fund.

DeYoung, R. \& Jang, K.Y. (2016). Do banks actively manage their liquidity? Journal of Banking \& Finance, 66, 143-161.

Duijm, P.\& Wierts, P. (2014). The effects of liquidity regulation on bank assets and liabilities. Tinbergen Institute Discussion Paper No. 14-018/IV/DSF72.

Elliot, D. (2014). Bank liquidity requirements: An introduction and overview. Online document available at:www.brookings.edu/ /media/research/files/papers/2014/06/23-bank-liquidity-requirementsintro-overview-elliot/23 bank liquidity requirements intro overview elliot.pdf

Farag, M., Harland, D. \& Nixon, D.(2013).Bank capital and liquidity. Bank of England Quarterly Bulletin, 53(3), 201-215.

Flannery, M.J. \& Hankins, K.W. (2013).Estimating dynamic panel models in corporate finance. Journal of Corporate Finance, 19, 1-19.

Gujarati, D.N. \& Porter, D.C. (1999). Essentials of econometrics (4th edition).McGraw Hill. New York, United States of America

Kok, C. \& Schepens, G. (2013). Bank reactions after capital shortfalls (No. 250).National Bank of Belgium Working Paper No. 250.

Kowalik, M. (2013). Basel liquidity regulation: Was it improved with the 2013 revisions?. Economic Review Federal Reserve Bank of Kansas City, 65.

Marozva, G. (2015). Liquidity and bank performance. The International Business \& Economics Research Journal, 14(3), 453:462

Molefe, B. \& Muzindutsi, P.F. (2016).Effect of capital and liquidity management on profitability of major South African banks.28 ${ }^{\text {th }}$ Annual Conference of the Southern African Institute of Management Scientists. University of Pretoria, South Africa.

Roodman, D. (2009). How to do xtabond2: An introduction to difference and system GMM in Stata. Stata Journal, 9(1), 86-136.

Schertler, A. (2010). Insights on banks' liquidity management: Evidence from regulatory liquidity data. Contributions to the anniversary of the Association for Socialpolitik 2010: Economy of the Family Session: Banking Regulation: Liquidity and Regulatory Capital, no. A7-V2

Vodová, P. (2013). Liquid assets in banking: What matters in the Visegrad countries? E+ M Ekonomie a Management, (3), 113. 